\title{
Enhanced Fiscal Governance in the European Union: The Fiscal Compact ${ }^{1}$
}

\author{
Merike Kukk \\ Department of Finance and Economics, \\ Tallinn University of Technology \\ Akadeemia tee 3-478, \\ Tallinn 12618, Estonia \\ E-mail:merike.kukk@ttu.ee \\ Karsten Staehr \\ Department of Finance and Economics, \\ Tallinn University of Technology \\ Akadeemia tee 3-486, \\ Tallinn 12618, Estonia \\ E-mail: karsten.staehr@ttu.ee
}

Abstract: Several reforms aiming to strengthen budgetary discipline in the European Union have been implemented since the outbreak of the European debt crisis. Arguably the most important one is the Fiscal Compact, which stipulates that each signatory country must enshrine in domestic legislation an upper limit on the structural budget deficit, that is, the deficit after cyclical and other temporary factors have been excluded. This paper analyses the contents of the Fiscal Compact and discusses challenges for its implementation and efficacy. The conclusion is that the Fiscal Compact may be challenging to implement and enforce because the rules are very complex and require complicated calculations that are subject to very large forecasting uncertainty. The Fiscal Compact could, however, lead to a stronger national commitment to fiscal prudence.

Keywords: cyclical adjustment, European Union, Fiscal Compact, fiscal rules,

This study was supported by the Estonian Science Foundation Target Financing Grant number SF0140059s12. The authors would take to thank, without implicating, an anonymous referee of the BJES and Ansgar Belke and other participants at the 2012 NBS conference on Fiscal policy and coordination in Europe for useful comments. The views expressed are those of the authors and not necessarily those of Eesti Pank. 


\section{macroeconomic governance}

\section{Introduction}

Coordination of economic policies has been a cornerstone of the European Union (EU) since its inception, but macroeconomic governance issues have gained particular attention with the introduction of the single currency. The Stability and Growth Pact (SGP) was approved in 1997 and aimed to ensure fiscal discipline by imposing common fiscal rules. The global financial crisis and the ensuing debt financing problems in several EU countries have led to a renewed focus on fiscal policy, and the result has been a host of reform measures meant to strengthen the macroeconomic governance frameworks of the EU.

A number of reform measures have sought to enhance fiscal governance, chief among them being the Fiscal Compact. The Compact was approved as an intergovernmental treaty in 2012 by most member countries of the European Union and it entered into force in January 2013. The Compact builds upon the SGP from 1997 and the revised SGP from 2005. Other measures such as the 'Six Pack' and the 'Two Pack' also contain measures that seek to enhance fiscal prudence and in part overlap with the Fiscal Compact.

The main innovations of the Fiscal Compact are that it introduces the structural budget balance as an operational target in fiscal policy and that it seeks to strengthen local "ownership" or responsibility for fiscal outcomes. The use of the structural balance as an operational target is meant to reduce the risk of procyclical fiscal policies while ensuring a benign development of the debt stock as a percentage of GDP.

An ECB bulletin provides a detailed account of the Fiscal Compact and compares the balanced budget rules of the Fiscal Compact with the rules of the reinforced SGP (ECB, 2012). The Occasional Paper by Frayne and Riso (2013) gives a comprehensive overview of the SGP, the Six Pack and the Two Pack, as well as the Fiscal Compact. The Fiscal Compact is discussed in only a few policyoriented studies (see Burret \& Schellenbach, 2013; Kullas et al., 2012; and the volume edited by Giancarlo Corsetti, 2012). There is a wide array of views on the possible efficacy of the Compact. Some of the authors claim that the Fiscal Compact is simply an instrument for forcing through fiscal austerity, and others find that the broad fiscal targets do not take country-specific features into account, while yet others believe that the Compact might be effective because it obliges countries to take on increased responsibility for fiscal management. 
This paper contributes to the literature in two different ways. First, it gives an overview and synthesis of the Fiscal Compact and other measures taken to enhance fiscal governance in the EU since the outbreak of the European debt crisis. Second, it seeks to assess the effectiveness of the Compact, in particular its effect on fiscal outcomes. Given the short time in which the Compact has been in force, any analysis of its efficacy must in large part be conceptual and discursive, but the analysis will be guided by a thorough review of the empirical literature on the effects of fiscal rules.

The rest of the paper is organised as follows. Section 2 outlines the contents of the Fiscal Compact and places it in the broader context of the evolution of fiscal governance in the EU. Section 3 reviews the empirical literature on the effectiveness of constraints on fiscal outcomes. Section 4 analyses the possible efficacy of the Fiscal Compact and pinpoints some challenges stemming from its implementation and enforcement. Section 5 concludes.

\section{The evolution of fiscal governance in the EU}

Coordination of economic policies is at the core of the European Union, but explicit criteria for fiscal outcomes were introduced only with the advent of the euro. The Stability and Growth Pact was agreed upon in 1997 and entered into force in 1998. It aimed to ensure sound government finances and to achieve that it included a preventative arm as well as a corrective arm (EC, 1997). The preventative arm set out both short-term and medium-term targets. In the short term, the annual general government deficit cannot exceed 3 per cent of GDP and the general government debt cannot exceed 60 per cent of GDP, or must be approaching this value "at a satisfactory pace". In the medium term, countries should aim for a fiscal balance "close to balance or in surplus", but no explicit limit was set as the limit for the headline deficit was deemed sufficient for that purpose.

The corrective arm of the SGP obliges the European Commission to monitor the fiscal performance of individual countries and to initiate an Excessive Deficit Procedure (EDP) against countries with a budget deficit in excess of 3 per cent of GDP. The EDP requires the country in question to present a plan for restoring compliance with the SGP; in the case of non-compliance a monetary fine can be imposed on the country.

The SGP was revised in 2005 (EC, 2005). The revision led to the use of the 
structural fiscal balance instead of the headline balance as the medium-term objective (MTO). The structural fiscal balance is computed by excluding temporary influences from the economic cycle and extraordinary factors from the headline balance. The definition of the medium-term objective was at the same time made more adaptable to extraordinary events. The revised SGP stipulated that the structural deficit could be at most 1 per cent of GDP for euro area countries or countries participating in the European Exchange Rate Mechanism II, the waiting-room for the euro area. Countries with an excessive deficit were recommended to correct the structural deficit by at least 0.5 percentage points of GDP per year.

The 2005 reforms introduced more flexibility in the implementation of the fiscal rules. It became easier for countries to avoid an EDP by referring to extraordinary developments such as severe economic downturns or "other relevant factors" which were beyond the control of governments. This greater discretion made the SGP more adaptable to country-specific features and might thus have enhanced enforceability (Morris et al., 2006). In practice, the immediate outcome of the SGP revision was that all ongoing EDPs were halted.

A host of reforms were introduced after the government debt crises that started in 2008 and affected several EU countries. The Six Pack measures entered into force in December 2011 (EC, 2012). The six components aimed to strengthen macroeconomic governance and the budgetary surveillance within the EU. The Six Pack launched the European Semester, which synchronises different surveillance processes. The MTO structural balance requirement is complemented by an expenditure benchmark and an explicit debt reduction target was introduced for debt exceeding 60 per cent of GDP. Furthermore, the EDP can be initiated if the debt criterion is violated. For the euro area, it is stipulated that financial sanctions can be applied in a step-wise fashion and that they are to be decided in the Council of Ministers by reverse qualified majority voting, that is, a financial sanction proposed by the European Commission can only be stopped by a qualified majority voting against it.

The Fiscal Compact is the core of the Treaty on Stability, Coordination and Governance in the Economic and Monetary Union, which was adopted at a Council of Ministers meeting in March 2012 and entered into force in January 2013 (EC, 2012). All members of the EU, except the Czech Republic and the United Kingdom, adopted the Compact and thereby undertook to implement the 
rules of the Compact in domestic legislation and fiscal policy implementation. ${ }^{2}$

The Fiscal Compact seeks to enhance the surveillance and coordination of fiscal policy with the aim of strengthening fiscal discipline. The Fiscal Compact stipulates that the budget of the general government must be "balanced or in surplus" (EC, 2012, p. 12). Each participating country must specify in national legislation a structural deficit ceiling for the medium term of 0.5 per cent of GDP or 1.0 per cent of GDP if the general government debt stock is below 60 per cent of GDP and there is no doubt about the sustainability of public finances. Where there are deviations from the MTO, an automatic correction mechanism enshrined in national legislation must ensure rapid convergence with the target.

The goal of keeping the structural deficit at or above 0.5 per cent of GDP may be restrictive given that various shocks can affect the budget balance significantly. The Fiscal Compact does, however, allow deviations under exceptional circumstances. An exceptional circumstance "refers to the case of an unusual event outside the control of the Contracting Party concerned which has a major impact on the financial position of the general government or to periods of severe economic downturn as set out in the revised Stability and Growth Pact" (EC, 2012, p. 13). An additional escape clause is included in the specification of the enforcement as deviations from the MTO or the adjustment path towards the MTO must be "significant" in order for the automatic correction mechanism to be triggered.

The Fiscal Compact requires that the MTO balanced budget rule must be included in national legislation in a binding and permanent way and that it must be overseen by a national fiscal council. This must take place "through provisions of binding force and permanent character, preferably constitutional, or otherwise guaranteed to be fully respected and adhered to throughout the national budgetary processes" (EC, 2012, p. 13).

The Two Pack, effective from 2013, adds a new additional European assessment of draft budgetary plans to the European Semester and strengthens the monitoring requirements for countries which are under an EDP (ECOFIN, 2013). The regulation obliges each signatory country to set up an independent body, a Fiscal Council, which is responsible for monitoring the fiscal performance and observing that the national fiscal rules are followed. The fiscal council is also responsible for overseeing the national implementation of the automatic

2 Croatia joined the EU in July 2013 and at the time expressed its commitment to sign up, while the Czech Republic stated its commitment to signing up in the spring of 2014. The eventual adoption was still pending for both countries at the end of 2014. 
correction mechanism stipulated in the Compact.

The main innovations of the Fiscal Compact and its supporting measures can be summarised in three points. First, the explicit structural fiscal deficit target is lowered to 0.5 per cent of GDP for countries with substantial public debt. Second, the requirement of a rapid return to the MTO target means that deviations from the target can only be short-lived, that is, the structural budget balance must play a central role in short-term fiscal policy formulation. Third, the MTO balanced budget rule must be enshrined in domestic legislation and overseen by a national fiscal council.

\section{Literature on the effects of fiscal rules}

To assess the possible effects of the Fiscal Compact and its supporting measures, it is informative to consider experiences from other cases in which fiscal rules have been applied. The seminal study by Kopits and Symansky (1998) summarises experiences of fiscal rules across developed and developing countries and across different levels of government. They arrive at a large number of, almost tautological, requirements for a well-designed and effective fiscal rule. The rule must be welldefined, transparent, simple, flexible, adequate, enforceable and consistent. The list is arguably so broad that no rule would satisfy all the requirements, but it does highlight the challenges of designing an effective fiscal rule.

Most states in the USA employ fiscal rules and constraints and the effect of these has been examined in a number of papers. Bohn and Inman (1996) find that the fiscal rules are only effective when they are enshrined in the constitution of the state and enforced by an independent supreme court. The results underscore the importance of the enforcement of fiscal rules. Poterba (1995) concludes from studies in which controls are included for political preferences that balanced budget rules probably have a separate effect. Fatas and Mihov (2006) show that fiscal rules are associated with less use of discretionary fiscal policy and also reduce the sensitivity of fiscal policy to business cycle movements. Poterba (1995) provides a survey of a large number of studies of fiscal rules in US states. Although most studies show that states with a balanced budget rule have a more prudent fiscal policy, the question is whether this is the result of the rule or the result of the preferences of the electorate or policy-makers in the state.

The results from emerging countries are generally not promising. Thornton (2009) investigates the impact of fiscal responsibility laws in nine emerging 
economies and finds that the laws did not have a significant effect on the fiscal balances; although at first sight the fiscal position of countries with fiscal responsibility laws seems to have improved, the same happened in countries without the laws.

Looking at studies focusing on the EU, Buti and Giudice (2002) evaluate the effect of the debt and deficit criteria of the Maastricht Treaty and find that the criteria were effective in the sense that the deficits of applicant countries were brought down. The paper takes a cautious approach to the effectiveness of the SGP and questions whether it will be possible to retain the political momentum resulting from the Maastricht criteria. Eichengreen et al. (1998) argue that the SGP would make policy-makers focus on improving the fiscal balance and ignore structural issues. Buti et al. (1998) argue that the most challenging part of the SGP would occur in the early stages after its implementation, when countries would make the transition to a balanced budget.

Annett (2006) evaluates the early experiences (1999-2004) of the Stability and Growth Pact. While the cyclically-adjusted balance seemed to improve for most of the small euro area countries and Spain, it deteriorated markedly for the large countries, Germany, France and Italy. Annett (2006, p. 13) concludes that a "key failing of the SGP in its early years was its inability to prompt countries to adjust during the periods of high growth". Some changes in the relative importance of budgetary institutions and political factors were also noted. Wyplosz (2005) and De Haan et al. (2004) reach similar conclusions, finding that the efficacy of fiscal rules depends on the institutional setting and that the enforcement mechanisms of the SGP are too weak.

Fatas and Mihov (2010) take a longer perspective and study fiscal policy in the euro area and in the OECD countries from 1970 to 2007. They find that fiscal policy has been slightly pro-cyclical in the euro area countries, while the SGP has not affected the cyclical behaviour of the structural balance. This is consistent with the findings of Ioannou and Stracca (2011), who explore a dataset of EU and non-EU countries to find a relationship between the fiscal rules introduced by the SGP and fiscal outcomes. They do not find any impact from the SGP on the primary fiscal balance.

The improved fiscal performance when countries sought to satisfy the Maastricht Treaty and in the immediate period after the introduction of the euro may in part have been due to "creative accounting". Milesi-Ferretti et al. (2004) examine the earlier period and conclude that in some cases where the gross debt stock was declining, the gross liabilities were increasing, so that the net consolidation was 
very modest. Von Hagen and Wolff (2006) consider the later period and find that some countries engaged in stock-flow adjustments that officially kept deficits down. This practice was particularly prevalent during recessions when the risk of breaking the 3 per cent deficit ceiling was large.

The findings are more positive for national rules. Marneffe et al. (2011) show that an index of fiscal rules decided and enforced domestically has statistically significant effects in panel data estimations for the euro area countries. More comprehensive rules are associated with an improved budget balance. The effectiveness of such domestic rules appears, however, to vary somewhat across countries. Moreover, since the study considers domestic rules, the result may also be attributed to differences in underlying preferences across the euro area countries. Only three countries in the euro area had no domestic fiscal rule in 2008, namely Greece, Cyprus and Malta.

The aims of reforming and extending the Stability and Growth Pact after the European debt crisis have been discussed by Schuknecht et al. (2011). They propose a number of additional measures to improve the implementation and enforcement of measures already in force. The upshot is that improved enforcement might have little effect and countries should instead receive support for institutional development and capacity building. This idea is supported by earlier studies about the governance and political economy issues of fiscal rules. Schuknecht (2004) zooms in on the political economy dimension of centrally imposed fiscal rules in the EU, finding that there may be a trade-off between the complexity of rules and the ability to enforce them, especially in countries with limited institutional capacity. Tallberg (2002) argues that the institutional and administrative capacity of the national governments in the EU is a binding constraint on the implementation of rules and regulations.

The conclusion is that most empirical studies find no or only weak evidence for an effect from supranational fiscal rules on the fiscal stance. This particularly applies if the institutional, administrative and political capacity is weak in the entity subjected to the rules. Fiscal rules with a clear domestic ownership appear to be more effective than supranational rules. These findings are important when the effectiveness of the Fiscal Compact is to be assessed. 


\section{Effects of the Fiscal Compact}

Section 2 concluded that the Fiscal Compact entailed a movement of the structural budget balance from its previous relatively subordinate position to effectively a short-term operational target codified in national law. The inclusion of the MTO and the associated correction mechanism in national law points to a greater national focus on fiscal surveillance. This section seeks to assess the possible efficacy of the Fiscal Compact in light of the findings from the literature surveyed in Section 3.

\subsection{Estimating the structural balance ex post and ex ante}

The structural fiscal balance is the cyclically adjusted balance adjusted for oneoff and temporary measures. The computation of the cyclically adjusted fiscal balance is very complex and this poses substantial challenges for its effective use as an operational target subject to surveillance by both the European Commission and the national fiscal council.

The cyclically adjusted fiscal balance is computed from the headline balance by subtracting the component which can be attributed to the business cycle stance, or the output gap of the economy. ${ }^{3}$ The output gap is computed as the logarithm of output minus the logarithm of potential output, where potential output is computed using the production function method (Larch \& Turrini, 2009). The output gap can thus be interpreted as the percentage deviation of output from potential output.

The country-specific sensitivities used in the computation of the cyclically adjusted balance depict the effect on the fiscal balance of a one percent deviation of output from its potential. The sensitivities are derived from a fairly complex methodology developed by the OECD (OECD, 2001; Larch \& Turrini, 2009). There have repeatedly been revisions to the methodology and sensitivities made available by the European Commission. In 2013, the previously used sensitivities were replaced by semi-elasticities (Mourre et al., 2013). In 2014, a new set of semi-elasticities was published based on estimations using an updated

3 If the cyclically adjusted budget balance is labelled CAB, the headline balance BAL, the output gap YGAP and the sensitivity of the budget balance to the output gap $\alpha$, then the cyclically adjusted budget balance can be expressed as CAB $=\mathrm{BAL}-\alpha \cdot \mathrm{YGAP}$, where a positive sensitivity $\alpha$ would suggest counter-cyclical fiscal behaviour.

4 The sensitivity is calculated as $d \mathrm{BAL} / d \mathrm{Y}$ while the semi-elasticity is calculated as $d(\mathrm{BAL} / \mathrm{Y}) /(d \mathrm{Y} / \mathrm{Y})$. 
dataset with data for the period 1990-2013 (Mourre et al., 2014). As a result, the estimated semi-elasticities were higher for most EU countries. ${ }^{5}$

Despite the revisions, the estimated semi-elasticities exhibit substantial model uncertainty and statistical uncertainty, but no quantitative measures of these uncertainties are reported in publicly available material from the European Commission. Moreover, the methods use historical data and assume that the semi-elasticities do not vary over the time period which may not be the case in practice.

Another, and arguably more important, problem is the uncertainties associated with estimation of the output gap (Larch \& Turrini, 2009; Marcellino \& Musso, 2010). The output gap is computed as actual output minus potential output. Statistics on actual output are available from statistics authorities, but forecasts of the output gap need to use forecasts of output. Such forecasts are evidently uncertain even within a time horizon of one year.

The potential output is computed using the production function method, which basically uses estimates of the availability, utilisation and productivity of the different production factors together with estimates of total factor productivity. The computation of potential output implies several sources of uncertainty. First, it will typically entail model uncertainty, including structural breaks, and uncertainty stemming from the estimation of the coefficients of the production function. Second, the estimates of factor utilisation and total factor productivity will to some extent depend on the cyclical position of the economy. This implies typically that production and unemployment forecasts are needed, at least for the year for which the potential output is calculated. The upshot is that forecasts of potential output even within a short horizon are very uncertain. ${ }^{6}$

The uncertainties regarding the computation of potential output come on top of the usual uncertainties in the statistics of fiscal variables. Much information is only available with a lag and preliminary estimates are often applied. Taking Ireland as a case in point, the real time estimation of the output gap for 2009 was 0.2 per cent of GDP, but the estimate was revised to -4 per cent of GDP in 2012 (McArdle, 2012). The result is revisions in fiscal variables, which can

5 For Estonia and Latvia the sensitivity parameters were 0.31 and 0.28 , respectively, while the 2014 semi-elasticity parameters are 0.44 and 0.38 , respectively. The increases have been of similar magnitude for Spain and France.

6 Marcellino and Musso (2010, p. 5) conclude succinctly with respect to monetary policy: "Despite their appealing characteristics as a relatively clear summary measure of overall slack in the economy, output gap estimates are problematic and represent a potentially misleading input in monetary policy analysis". 
be substantial. Paloviita (2012) explores the uncertainty in euro area fiscal policies due to real time uncertainty and finds that the real time uncertainty has an important role in unexpected fiscal outcomes. Some of the uncertainties and possible biases might, however, be associated with the institutional and political features of the individual country (Cimadomo, 2011). Frankel and Schreger (2013) find that the forecasts of euro area governments are biased upward and that the forecasts are particularly optimistic when the governments have difficulties in meeting their MTOs.

The discussion above suggests that forecasts of the cyclically adjusted balance one year ahead or even within the year are subject to very large uncertainty. Large and rapid changes in output make it particularly complicated to estimate the potential output. This point can be illustrated by considering the estimates of the cyclically adjusted balance of Latvia published by the European Commission. In the Autumn Forecast 2007, when the preparation of the budget for the next year was in its final stages, the cyclically adjusted balance for 2008 was estimated to be positive and equal to 0.5 per cent of GDP. In later forecasts, the cyclically adjusted balance for 2008 was adjusted downwards, and in the Spring Forecast 2012 the cyclically adjusted balance for 2008 was reported as -6.5 per cent of GDP. The example is extreme, but revisions of one or more percentage points are not uncommon for this period.

Beyond the complications and uncertainties associated with the computation of the cyclically adjusted balance, there may be similar problems in the computation of one-off and temporary measures. It is by definition impossible to delineate all transactions that may be classified as one-off and temporary, and this may leave the authorities with substantial discretion in the classification of various spending and revenue components. The authorities may in some cases be able to allude to exceptional circumstances which affect the fiscal balance negatively so that the structural balance target cannot be met. Various shocks will undoubtedly affect the fiscal balance and hence the structural fiscal balance, but it is challenging to delineate the types of shock that reflect exceptional circumstances and shocks that fall outside this category. ${ }^{7}$

To illustrate the implications of repeated revisions, Figure 1 (see the next page) depicts the assessment of structural balance for 2011 in a number of countries, provided by the European Commission in the autumn forecasts of different

7 The fact that the Fiscal Compact allows for some discretionary adjustment in exceptional circumstances related to unusual shocks and severe recessions may be seen as an admission of the numerous problems associated with the computation of the cyclically adjusted balance. 
years. Even after the period of main data revisions induced by the crises, the revisions continue to be substantial. The structural balance for Estonia has been revised to be 0.5 percentage point smaller in 2011, while in Spain the revisions exceed one percentage point. The major revisions do not apply only to the countries in Central and Eastern Europe or Southern Europe, as the assessment of the structural deficit for Finland in 2011 was increased by 1.1 percentage points from 2012 to 2014.

Figure 1. The structural budget balance of the general government in 2011, $\%$ of GDP

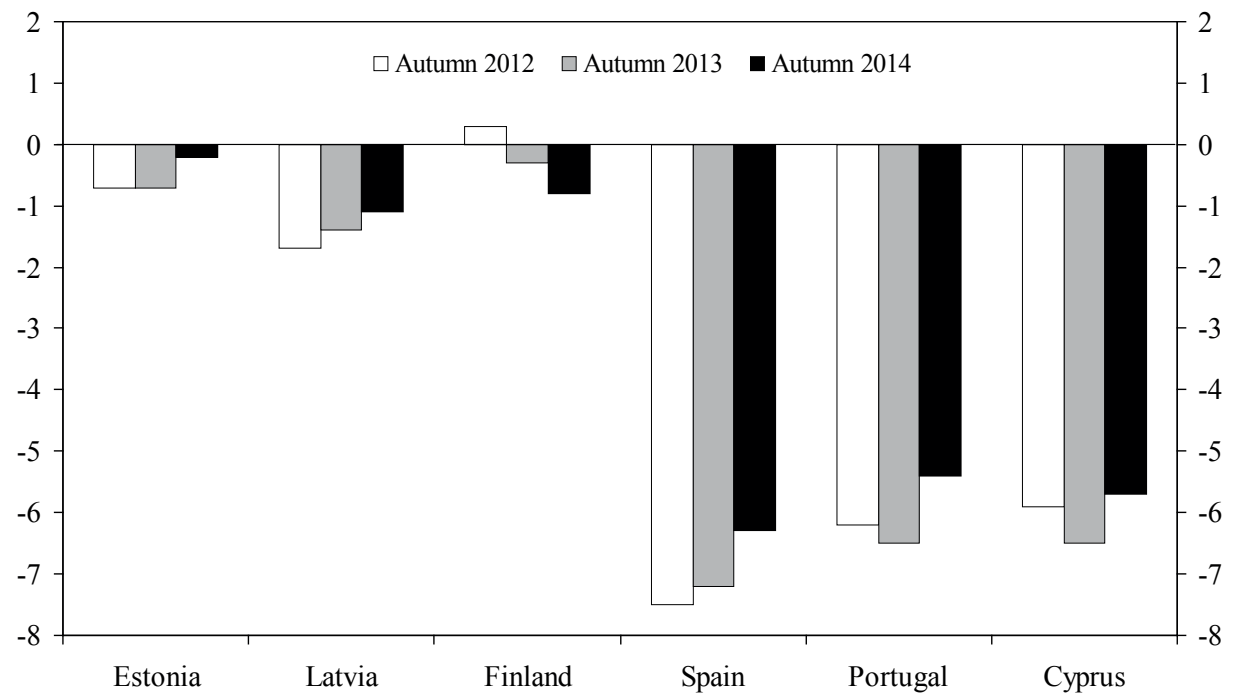

Note: European Commision estimates of the structural budget balance for 2011 as published in the autumn forecast 2012-2014.

While it is challenging to estimate the structural budget balance ex post, it is even more challenging ex ante. Fiscal policy formulation typically starts more than half a year before the start of the fiscal year and with such a horizon the forecasts of the structural balance for the next year would be very uncertain due to uncertainty about the output gap, other shocks to the fiscal balance and statistical errors. The forecast uncertainty complicates the implementation of a policy seeking to satisfy the target in the Fiscal Compact of a structural deficit of at most 0.5 per cent of GDP (or 1 per cent of GDP for countries with a relatively strong debt performance).

The empirical literature survey in Section 3 brought up two main findings. First, supranationally imposed fiscal rules have generally been ineffective, 
especially when the rules have been complex and difficult to implement and monitor. Second, rules that are decided nationally and have national ownership have generally exhibited the best results. The supranational nature of the treaty suggests the effect of the Fiscal Compact on the structural balance cannot be taken for granted. However, as discussed in Section 2, the Compact also seeks to establish national ownership of the structural balance target and this may be an important factor that enhances fiscal prudence and hence the efficacy of the Fiscal Compact.

\subsection{The estimated structural balance in practice}

The discussion above highlights the challenges of using the structural balance as an operational target, and these challenges affect implementation, surveillance and inducement. A critical view would assert that an operational target for the structural balance is rather problematic; the cyclically adjusted balance is unobservable and is computed from the output gap, which is another unobservable variable, and a sensitivity coefficient, which is estimated imprecisely.

Turning to the implementation, the prudent response to the different uncertainties would arguably be to operate with a large expected structural surplus in order to ensure that the probability of the criterion in the Fiscal Compact being breached is small. In other words, the uncertainty associated with the computation of the structural balance could, in principle, lead to more cautionary or prudent fiscal plans. Such a precautionary approach may, however, lead to a contractionary fiscal policy that may be unwarranted in some circumstances. Bird and Mandilaras (2013) and Creel et al. (2012) underscore that there is an asymmetry in fiscal rules that discourage structural fiscal deficits but not structural fiscal surpluses.

The uncertainty and the possibility of discretionary adjustment may alternatively be used by governments to report overly optimistic forecasts of the structural fiscal balance so that they can fulfil on paper the requirements of the Fiscal Compact. The uncertainty and the possibilities for various adjustments may also be used as arguments or excuses if it turns out ex post that the structural balance breaches the limit. Governments may challenge the complicated and non-transparent methodology used to estimate the fiscal measures. France was in 2014 requested by European Commission to reduce its structural deficit substantially but in the end carried out only a modest reduction (EUobserver, 2014; The Economist, 2014). 
Given the many difficulties in estimating and implementing the structural balance as a short-term target, it is not surprising that most EU countries have not met the structural deficit target of the Fiscal Compact. Table 1 shows data on the structural balance for the euro area countries (before the entry of Lithuania). The data for 2012 and 2013 are ex post estimations, while data for 2014 and onward are the autumn forecasts of European Commission. Although the budget balance improved substantially in most euro area countries in 2012-2013, the budget loosened in 2014 compared to 2013 in six of the countries that did not meet the deficit target of 0.5 per cent. The structural budget is projected to worsen in 2015 in seven countries and in 2016 in eight countries in which the balance is below -0.5 per cent.

Table 1: Structural budget balance of general government for euro area countries, $\%$ of GDP

\begin{tabular}{|l|c|c|c|c|c|}
\hline & $\mathbf{2 0 1 2}$ & $\mathbf{2 0 1 3}$ & $\mathbf{2 0 1 4}$ & $\mathbf{2 0 1 5}$ & $\mathbf{2 0 1 6}$ \\
\hline Belgium & -3.12 & -2.69 & -2.63 & -2.24 & -2.29 \\
\hline Germany & 0.04 & 0.59 & 0.71 & 0.61 & 0.53 \\
\hline Estonia & -0.37 & -1.14 & -0.78 & -0.69 & -0.71 \\
\hline Ireland & -7.08 & -4.76 & -3.77 & -3.33 & -3.29 \\
\hline Greece & 0.05 & 3.14 & 2.02 & 1.63 & 0.97 \\
\hline Spain & -3.62 & -2.33 & -2.16 & -2.34 & -2.83 \\
\hline France & -4.27 & -3.28 & -3.03 & -2.93 & -3.42 \\
\hline Italy & -1.64 & -0.80 & -0.90 & -0.81 & -1.03 \\
\hline Cyprus & -5.49 & -2.12 & -0.84 & -1.33 & -1.05 \\
\hline Latvia & -0.05 & -1.03 & -1.47 & -1.64 & -1.52 \\
\hline Luxembourg & 1.54 & 2.02 & 1.11 & 0.40 & -0.06 \\
\hline Malta & -3.84 & -2.71 & -2.75 & -2.92 & -2.36 \\
\hline Netherlands & -2.23 & -0.60 & -0.54 & -0.81 & -1.06 \\
\hline Austria & -1.84 & -1.27 & -1.11 & -1.00 & -0.69 \\
\hline Portugal & -2.31 & -1.94 & -1.35 & -1.67 & -2.01 \\
\hline Slovenia & -1.82 & -1.81 & -2.51 & -2.19 & -2.83 \\
\hline Slovakia & -3.39 & -1.36 & -2.10 & -1.28 & -1.14 \\
\hline Finland & -1.05 & -0.73 & -1.10 & -1.10 & -1.32 \\
\hline Euro area & -2.11 & -1.19 & -1.09 & -1.10 & -1.34 \\
\hline
\end{tabular}

Source: The Ameco database by the European Commission. 
At the end of 2014, it is too early to draw any firm conclusions about the effect of the Fiscal Compact on the fiscal stance. Table 1 suggests that the initial effect is likely to be very modest; there is no clear evidence that countries tightened fiscal policy and improved their structural balance after the Fiscal Compact was introduced in 2013.

\section{Final comments}

The European Union can be seen as an institution seeking to address issues of mutual interdependence while allowing for a high degree of decentralised policy-making. The Fiscal Compact may be seen as another measure seeking to attend to the inherent conflict between these two objectives. The Fiscal Compact was agreed upon in 2012 after some political debate and with two EU countries, the Czech Republic and United Kingdom, deciding not to participate.

The Compact represents only incremental changes in the existing overall framework for fiscal governance in the EU, in particular the revised SGP from 2005 and the more recent Six Pack and Two Pack. The Fiscal Compact is in this context an addition to an already extensive set of treaties and legislation on macroeconomic governance in the EU. The many detailed preventative and corrective measures may be seen to address issues that are of great importance for the functioning of the EU and the euro area. However, the complex framework may at the same time be seen to hamper implementation and enforcement and also to limit public appreciation of the objectives.

The Fiscal Compact turns the structural balance into an operational target so that fiscal policy-making must ensure that there is a very small probability of the limit being breached. The use of the structural balance as an operational target has the advantage of reducing the risk of pro-cyclical fiscal policies. The target, however, has several disadvantages that mainly stem from the uncertainties of the calculation and the forecasting of the cyclically adjusted balance, and from the possibilities for discretionary adjustments of the structural balance. The uncertainties complicate the implementation and enforcement of the structural deficit target and may also provide scope for misrepresentation and concealment of information. It is precisely for these reasons that the national ownership of the structural balance target is of fundamental importance for the efficacy of the Fiscal Compact. 
It should finally be emphasised that even if the Fiscal Compact does eventually lead to stronger fiscal positions in the participating EU countries, it is unclear to what extent this would contribute to reducing government financing crises. Government debt crises have many causes. A government financing crisis occurs when a country cannot borrow at any reasonable cost because of a lack of confidence in financial markets. Sentiment shifts may occur because of developments in economic fundamentals such as the fiscal position of the government, but possibly also because of other factors such as growth prospects. Experience has shown that developments in the banking sector and financial markets in general can change fast with possible negative consequences for the fiscal position. Finally, crises may occur due to sentiment shifts in financial markets that are largely unrelated to economic fundamentals. These considerations suggest that the Fiscal Compact and its focus on the structural budget balance will be at most only one factor contributing to enhanced fiscal sustainability in the EU.

Merike Kukk is PhD student and research scientist at the Department of Finance and Economics at Tallinn University of Technology, Estonia. She is giving courses in macroeconomics and fiscal policy to undergraduate and master students. Her research topics cover household finance and consumption, tax evasion and fiscal policy. She has consulted commercial banks and has written analyses about household behaviour in the Baltic States. She has also been a visiting researcher at Eesti Pank, the central bank of Estonia.

Karsten Staehr is professor of international and public finance at the Department of Finance and Economics at Tallinn University of Technology, Estonia, and a part-time research supervisor at Eesti Pank, the central bank of Estonia. He holds a master's degree from the Massachusetts Institute of Technology and master's and PhD degrees from the University of Copenhagen. He undertakes research and policy analysis within public economics, monetary economics and transition studies. 


\section{References}

Annett, A. (2006), Enforcement and the Stability and Growth Pact: how fiscal policy did and did not change under Europe's fiscal framework, IMF Working Paper, no. 06/116, International Monetary Fund.

Bird, G. \& Mandilaras, A. (2013), 'Fiscal imbalances and output crises in Europe: will the fiscal compact help or hinder?' Journal of Economic Policy Reform, vol. 16, no. 1, pp. 1-16. http://dx.doi.org/10.1080/17487870.2013.765081

Bohn, H. \& Inman, R. P. (1996), 'Balanced budget rules and public deficits: evidence from the U.S. states,' Carnegie-Rochester Conference Series on Public Policy, vol. 45, pp. 13-76. http://dx.doi.org/10.1016/S0167-2231(96)00017-6

Burret, H. T. \& Schnellenbach, J. (2013), Implementation of the Fiscal Compact in the Euro Area Member States, Working Paper, no. 8, German Council of Economic Experts.

Buti, M.; Franco, D. \& Ongena, H. (1998), 'Fiscal discipline and flexibility in EMU: the implementation of the Stability and Growth Pact,' Oxford Review of Economic Policy, vol. 14, no. 3, pp. 81-97. http://dx.doi.org/10.1093/oxrep/14.3.81

Buti, M. \& Giudice, G. (2002), "Maastricht's fiscal rules at ten: an assessment," Journal of Common Market Studies, vol. 40, no. 5, pp. 823-848. http://dx.doi.org/10.1111/1468-5965.00399

Cimadomo, J. (2011), Real-time data and fiscal policy analysis. A survey of the literature, ECB Working Paper Series, no. 1157, European Central Bank.

Corsetti, G., ed. (2012), Austerity: too much of a good thing? A VoxEU.org eCollection of views by leading economists, Centre for Economic Policy Research. Retrieved from http://www.voxeu.org/sites/default/files/file/austerity_ecollection.pdf [accessed 12 Jan 2014]

Creel, J.; Hubert, P. \& Saraceno, F. (2012), 'The European fiscal compact: a counterfactual assessment,' Journal of Economic Integration, vol. 27, no. 4, pp. 537-563. http://dx.doi.org/10.11130/jei.2012.27.4.537

De Haan, J.; Berger, H. \& Jansen, D. J. (2004), 'Why has the Stability and Growth Pact failed?' International Finance, vol. 7, no. 2, pp. 235-260.

http://dx.doi.org/10.1111/j.1367-0271.2004.00137.x

EC (1997), Resolution of the European Council on the Stability and Growth Pact Amsterdam, C 236, European Council, 17.06.1997. Retrieved from http://eur-lex. europa.eu/legal-content/EN/ALL/?uri=CELEX:31997Y0802(01) [accessed 12 Jan 2015]

(2005), 'Improving the implementation of the Stability and Growth Pact,' Presidency Conclusions, 7423/05, European Council Brussels, 22/23.03.2005, Annex II. Retrieved from http://ec.europa.eu/research/era/docs/en/council-eu-19. pdf [accessed 12 Jan 2015] 
(2012), Treaty on Stability, Coordination and Governance in the Economic and Monetary Union, European Council, 02.03.2012. Retrieved from http://europeancouncil.europa.eu/media/639235/st00tscg26 en12.pdf [accessed 12 Jan 2015]

ECB (2012), 'A Fiscal Compact for a stronger Economic and Monetary Union,' European Central Bank Monthly Bulletin, May, pp. 79-94.

ECOFIN (2013), 'Specifications on the implementation of the Two Pack and Guidelines on the format and content of draft budgetary plans, economic partnership programmes and debt issuance reports,' Two Pack Code of Conduct, Economic and Financial Affairs Council, 9 July 2013. Retrieved from http://ec.europa.eu/ economy_finance/economic_governance/sgp/pdf/coc/130701-two_pack_coc_ final_endorsed.pdf [accessed 12 Jan 2015]

Eichengreen, B.; Wyplosz, C.; Bean, C. \& Gerlach, S. (1998), 'The Stability Pact: more than a minor nuisance?' Economic Policy, vol. 13, no. 26, pp. 65-113. http://dx.doi.org/10.1111/1468-0327.00029

EUobserver (2014), 'France gets three months to tweak budget,' 28 November. Retrieved from http://euobserver.com/economic/126720 [accessed 12 Jan 2015]

Fatas, A. \& Mihov, I. (2006), 'The macroeconomic effects of fiscal rules in the US states,' Journal of Public Economics, vol. 90, nos. 1-2, pp. 101-117. http://dx.doi.org/10.1016/j.jpubeco.2005.02.005 (2010), 'The euro and fiscal policy,' in A. Alesina \& F. Giavazzi (eds.) Europe and the Euro, Chicago: University of Chicago Press, pp. 287-324. http://dx.doi.org/10.7208/chicago/9780226012858.003.0009

Frankel, J. \& Schreger, J. (2013), 'Over-optimistic official forecasts and fiscal rules in the Eurozone,' Review of World Economics, vol. 149, no. 2, pp. 247-272. http://dx.doi.org/10.1007/s10290-013-0150-9

Frayne, C. \& Riso, S. (2013), Building a Strengthened Fiscal Framework in the European Union: A Guide to the Stability and Growth Pact, European Economy, European Commission, Occasional Paper, no. 150.

Ioannou, D. \& Stracca, L. (2011), Have Euro Area and EU Economic Governance Worked? Just the Facts, European Central Bank Working Paper Series, no. 1344.

Kopits, G. \& Symansky, S. A. (1998), Fiscal Policy Rules, IMF Occasional Paper, no. 162, International Monetary Fund.

Kullas, M.; Sauer, O. \& Hohmann, I. (2012), Fiscal Compact, CEP Policy Brief, no. 2012-13, Centrum für Europäische Politik. Retrieved from http://www.cep. eu/fileadmin/user_upload/Kurzanalysen/Fiskalpakt/PB_Fiscal_Compact.pdf [accessed 12 Jan 2015]

Larch, M. \& Turrini, A. (2009), The cyclically-adjusted budget balance in EU fiscal policy making: A love at first sight turned into a mature relationship, European Economy: Economic Papers, no. 374, European Commission. 
Marcellino, M. \& Musso, A. (2010), Real Time Estimates of the Euro Area Output Gap. Reliability and Forecasting Performance, European Central Bank Working Paper Series, no. 1157.

Marneffe, W.; Van Aarle, B; Van Der Wielen, W. \& Vereeck, L. (2011), The Impact of Fiscal Rules on Public Finances in the Euro Area, CESifo DICE Report 3/2011. Retrieved from http://www.cesifo-group.de/portal/pls/portal/docs/1/1211672.pdf [accessed 12 Jan 2015]

McArdle, P. (2012), The Euro Crisis: The 'Fiscal Compact' and Fiscal Policy, IIEA Working Paper, no. 6, Institute of International and European Affairs.

Milesi-Ferretti, G. M. \& Moriyama, K. (2004), Fiscal Adjustment in EU Countries: A balance Sheet Approach, IMF Working Paper, no. WP/04/143, International Monetary Fund.

Morris, R.; Ongena, H. \& Schuknecht, L. (2006), The Reform and Implementation of the Stability and Growth Pact, ECB Occasional Paper Series, no. 47, European Central Bank.

Mourre, G.; Astarita, C. \& Princen, S. (2014), Adjusting the Budget Balance for the Business Cycle: The EU Methodology, European Economy: Economic Papers, no. 536, European Commission.

Mourre, G.; Isbasoin, G.-M.; Paternoster, D. \& Salto, M. (2013), The cyclicallyadjusted budget balance used in the EU fiscal framework: an update, European Economy: Economic Papers, no. 478, European Commission.

OECD (2001), Structural Budget Balances: A Methodological Note, Organisation for Co-operation and Development. Retrieved from www.oecd.org/ dataoecd/0/61/36336878.pdf [accessed 12 Jan 2015]

Paloviita, M. (2012), Real Time Uncertainty in Fiscal Planning and Debt Accumulation in the Euro Area, Discussion Papers, no. 34, Bank of Finland Research.

Poterba, J. M. (1995), 'Balanced budget rules and fiscal policy: evidence from the states,' National Tax Journal, vol. 48, no. 3, pp. 329-336.

Schuknecht, L. (2004), EU Fiscal Rules Issues and Lessons from Political Economy, ECB Working Paper Series, no. 421, European Central Bank.

Schuknecht, L.; Moutot, P.; Rother, P. \& Stark, J. (2011), The Stability and Growth Pact: Crisis and Reform, ECB Occasional Paper, no. 129, European Central Bank.

Tallberg, J. (2002), 'Paths to compliance: enforcement, management, and the European Union,' International Organization, vol. 56, no. 3, pp. 609-643. http://dx.doi. org/10.1162/002081802760199908

The Economist (2014), 'Budget, fudge it,' 1-7 November 2014, p. 25.

Thornton, J. (2009), 'Do fiscal responsibility laws matter? Evidence from emerging market economies suggests not,' Journal of Economic Policy Reform, vol. 12, no. 2, pp. 127-132. http://dx.doi.org/10.1080/17487870902872912 
Von Hagen, J. \& Wolff, G. B. (2006), 'What do deficits tell us about debt? Empirical evidence on creative accounting with fiscal rules in the EU,' Journal of Banking \& Finance, vol. 30, no. 12, pp. 3259-3279. http://dx.doi.org/10.1016/j. jbankfin.2006.05.011

Wyplosz, C. (2005), 'Fiscal policy: institutions versus rules,' National Institute Economic Review, vol. 191, no. 1, pp. 64-78. http://dx.doi.org/10.1177/0027950105052661 